\title{
ANALYSIS OF CONSEQUENCES OF A DESIGN BASIS EARTHQUAKE FOR THE REGION AROUND A NUCLEAR POWER PLANT
}

\author{
${ }^{1}$ András VILIMI, ${ }^{2,3}$ László TÓTH, ${ }^{4,5}$ Tamás János KATONA \\ ${ }^{1}$ MVM Nuclear Power Plant Paks Ltd, 7031 Paks, P.O. Box 71, e-mail: vilimi@npp.hu, \\ ${ }^{2}$ Institute of Geodesy and Geophysics, Research Centre for Astronomy and Earth Sciences, \\ Hungarian Academy of Sciences, \\ ${ }^{3}$ GeoRisk Earthquake Engineering, Budapest, \\ ${ }^{4}$ MVM Nuclear Power Plant Paks Ltd. 7031 Paks, P.O. Box 71, \\ ${ }^{5}$ University of Pécs, János Szentágothai Research Center H-7624 Pécs, Ifjúság útja 20
}

Received 10 December 2015; accepted 25 January 2016

\begin{abstract}
In the paper a study is presented for the case if a $10^{-4} / \mathrm{a}$ annual probability design basis earthquake would hit area surrounding the Nuclear Power Plant Paks. Although the plant can be brought to safe shutdown condition and there is no need for off-site protective measures, the plant personnel will need a minimum of logistical support from and communication with the outside area. Therefore, the knowledge of the post-earthquake situation is required for planning of the logistical support of the plant accident management and for the understanding the working conditions for disaster management services. Parameters of the case-study earthquake are selected in accordance with the design basis of the plant. Distribution of population and housing data used in this study has been obtained by population census held in 2011. The study can also help to communicate the seismic safety of the plant showing the disastrous consequences of design basis earthquake while the plant remains safe.
\end{abstract}

Keywords: Damage, Earthquake, Intensity, Damage grade, Condition assessment of housing

\section{Introduction}

Nuclear Power Plants (NPP) have to be designed for all foreseeable at the site external hazards that can adversely affect the plant safety. According to the international practice, the frequency of the core damage and the early large release of radioactive substances into the environment have to be limited to the values of $10^{-5} / \mathrm{a}$ and $10^{-6} / \mathrm{a}$, respectively. Because of these limitations, criterion for damage parameters of the hazards to be accounted in the design is set to the level of $10^{-4} \div 10^{-5}$ probabilities per annum. Proper design of the plant ensures that the Systems, Structures and Components 
(SSCs) that required for ensuring the plant safety remain functional both during and after the external event avoiding melting of the reactor core. The structures and systems required for accident management have to remain functional even in case of beyond design basis external events. The plant staff and the disaster management services of the country have to be prepared to manage extreme events and mitigate their consequences. This requirement has been formulated after the Fukushima accident and also adopted in the national regulations [1] and [2].

In general, the plant design includes also the plant and site layout, which are very important for safety in relation to external hazards. However, the emergency planning and response requires evaluation of the consequences of external events beyond the scope of the plant design. An extreme disastrous rare external event will cause catastrophic consequences in large area around the plant site. The post-event conditions around the site affect the logistical support of the emergency actions at the plant, influence the psychological condition of the plant personnel, and determine the workload of the country's disaster management personnel.

In the paper a hypothetical case study is presented: What would happen outside of the Paks Nuclear Power Plant, if a $10^{-4}$ annual probability earthquake would happen? In this case the plant should be brought to safe shutdown condition thanks to the seismic safety upgrading measures implemented and there is no need for off-site protective measures [3]. Although the plant safe shutdown is ensured, the plant personnel will need a minimum of logistical support from and communication with the outside area. Therefore the results of the study can be used for planning of the logistical support of the plant accident management staff. The study also contributes to better understanding the working conditions of the disaster management services in the area of the nuclear power plant. The importance of assessment of post-event situation has been recognized by competent authorities in Hungary; see, e.g. [4], [5] and [6]. The importance of systematic planning for disaster management is recognized in countries endangered by natural hazards. There are plenty of studies related to loss estimation methodology (see, e.g. [7]), and the principles for resilience and disaster management are summarized e.g. in [8] and [9]. However, there are rather limited examples for detailed earthquake damage forecasts for low-to-moderate seismicity regions [10], [11].

The study can help to communicate the seismic safety of the plant via demonstrating the disastrous conditions that may happen in case of design basis earthquake while the plant remains safe. The parameters (magnitude, focal depth and possible distance from the site) of the case-study earthquake are selected in accordance with the design basis of the Paks Nuclear Power Plant). For evaluation of the damages of the built environment instrumental intensity map (shake-map) has been developed for the earthquake that is dominating the site seismic hazard. The distribution of population and housing data used in the study have been obtained by population census held in 2011 and published by the Hungarian Central Statistical Office [12]. Based on these data the damages have been assessed using European Macroseismic Intensity Scale [13] and the corresponding phenomenological definition of damages. This methodology can be considered as a simplification of the methods given in [10], [11] and [14]. 


\section{Definition of the case-study earthquake}

Probabilistic Seismic Hazard Assessment (PSHA) performed for the Paks NPP site provides the hazard curves for probability levels up to $10^{-7}$ annual probabilities of exceedance, as well as the Uniform Hazard Response Spectra for the base-rock. Deaggregation of the hazard has been performed for $10^{-4} /$ a (see Fig. 1).

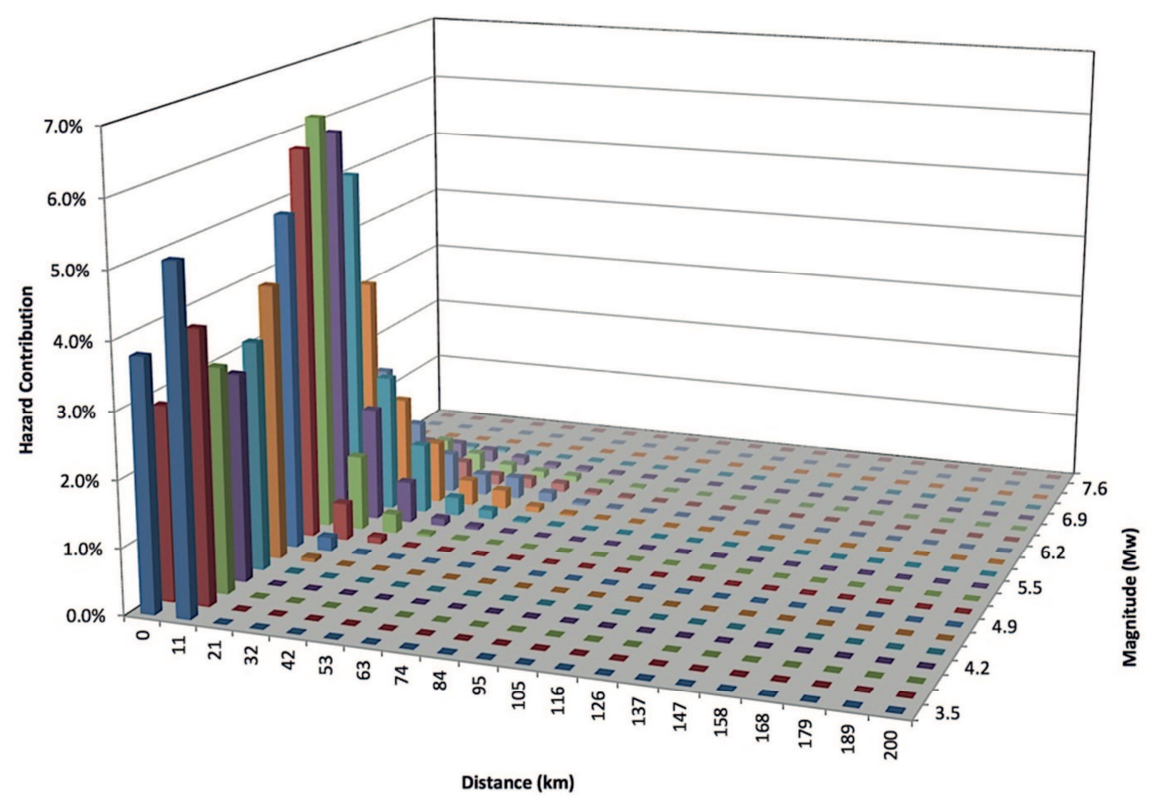

Fig. 1. Magnitude-distance deaggregation for $10^{-4} /$ a level peak ground acceleration

According to this, an earthquake of moment magnitude 5.8-6.0 at an epicentral distance of $\sim 10 \mathrm{~km}$ from the plant site is dominating in the hazard. The free-field ground motion has been obtained by non-linear site response analysis. The design basis Peak Ground Acceleration (PGA) is equal to $0.25 \mathrm{~g}$. For comparison, a PGA of $0.09 \mathrm{~g}$ had to be accounted for the Paks site, if the EUROCODE 8 would be applied for a very important structure with 50 years' service life.

Based on the seismic hazard assessment of Paks NPP site, two scenarios has been chosen for the study as follows:

1. An earthquake of $\mathrm{M}=6.2$ is assumed to occur at $\sim 10 \mathrm{~km}$ epicentral distance North-East from the NPP site (Dunapataj, coordinates: 46.64; 19:00);

2. The same size earthquake as defined above happens in the vicinity of the plant.

Analysis of the first scenario provides an insight how devastating could be and earthquake comparable to the plant Design Basis Earthquake for the area nearby the site. 
Analysis of the second case provides an impression, what would happen in the settlements where dwellings of the majority of the plant personnel are located. The second case analysis also demonstrates the logistical hurdles in supporting the work of plant emergency services personnel.

The intensity map of the second scenario looks like practically identical to the intensity map plotted in Fig. 2. The basic difference is that city Paks and the surrounding the sites villages are impacted in this case since the epicentre of the quake is moved to the NPP site.
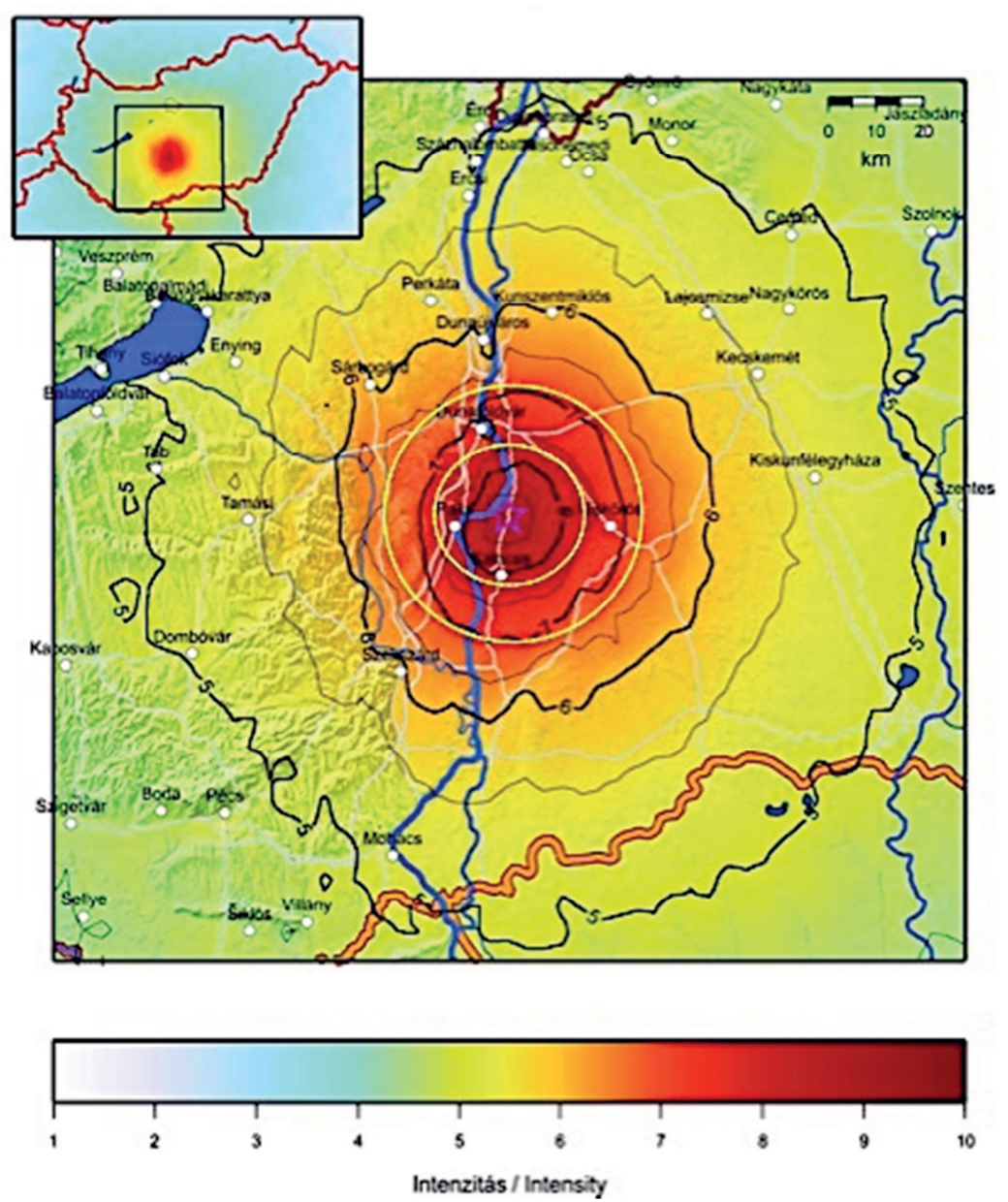

Fig. 2. Instrumental intensity map of the Scenario 1 earthquake

The local soil conditions strongly influence the damages in housing and infrastructure caused by the earthquake. The plant site located at the contact area of aerial loess sediments of Transdanubia and very thick fluvial sediments of Great 
Hungarian Plain. At the flood-plain of the Danube the surface is covered by Pleisctocene fluvial gravel, gravelly sand (7-10 m), sand, fine grained sand (10-15 m) and Holocene fluvial fine grained sand, gravel, eolic sand. Under relatively thin Quaternary sediments there are several hundred meters of Pannonian and underlying, variable Miocene layers. The West side of the area is covered mainly wind-blown Quaternary sediments, mainly loess. Under these 20-100 m thick Quaternary layers lie Upper Pannonian layers on the whole territory. At the flood plain continuous shallow groundwater regime is in place that is influenced by the Danube level. Depth of ground water level is about 7-10 m below ground surface or even less at many places. The uppers soil at the flood-plain can be classified as $\mathrm{C}$ or $\mathrm{D}$ according to EUROCODE 8 while the soil at West side belongs mainly to the class B and C. The loose, saturated and non-cohesive sandy soils susceptible to liquefaction that appears as an additional hazard to the earthquake and may cause some further damages. Earthquake sites with similar soil conditions show the evidences of liquefaction hazard cases [7].

\section{Distribution of population and housing data}

There are 75 settlements with 220911 inhabitants in the $30 \mathrm{~km}$ radius area around Paks Nuclear Power Plant. The settlements could be divided to 11 towns (Dunaföldvár, Gyönk, Hajós, Kalocsa, Kecel, Kiskőrös, Paks, Simontornya, Solt, Szekszárd and Tolna) and to 64 villages. The town-village and population-ratio in 2012 was $58.1 \%$. In the $10 \mathrm{~km}$ radius area around the NPP live 41590 people. The settlements are: Dunapataj, Fadd, Gerjen, Ordas, Tengelic, Dunaszentbenedek, Foktő, Györköny, Paks, Uszód, Dunaszentgyörgy, Géderlak, Madocsa and Pusztahencse. The only town is here Paks.

At the census of 2011 in the statistical unit of Paks, Kalocsa and Szekszárd the $44.3-55.0 \%$ of the residences were bricks masonry buildings. The adobe-walled buildings ratio was about 20.1-30.0\% in Tolna County and around 30.1-39.8\% in BácsKiskun County. Basic data are shown in Table I and Table II.

Table I

Type of buildings in villages of Bács-Kiskun County

\begin{tabular}{|l|c|}
\hline Type of structure & Shear, $\%$ \\
\hline brick, stone, masonry hand-made & 40.9 \\
medium or large block, cast concrete & 6.1 \\
panel & 0.1 \\
wood & 0.3 \\
adobe, mud with foundation & 33.2 \\
adobe, mud without foundation & 18.1 \\
others & 1.3 \\
\hline Total: & 100 \\
\hline
\end{tabular}


Table II

Type of buildings in cities of Bács-Kiskun County (except Kecskemét)

\begin{tabular}{|l|c|}
\hline Type of structure & shear, \% \\
\hline brick, stone, masonry hand-made masonry & 48.1 \\
medium or large block, cast concrete & 7.4 \\
panel & 7.6 \\
wood & 0.2 \\
adobe, mud with foundation & 25.1 \\
adobe, mud without foundation & 10.4 \\
others & 1.3 \\
\hline Total: & 100 \\
\hline
\end{tabular}

The brick/masonry structures as well as the adobe structures dominate $(92.2 \%)$ in the villages. The $28 \%$ of the residences were built before 1946. In the Bács-Kiskun cities (except Kecskemét) the shear of brick masonry is dominating and the shear of adobe buildings is much less than in those in the villages. In the cities $21 \%$ of the residences were built before 1946 . The construction date has practical importance since the newly constructed buildings with reinforced masonry walls have rather high shear resistance [15].

The shear of adobe structures in Tolna County varies between 20 and 31\%, i.e. it is significantly less than in Bács-Kiskun County.

\section{Assessment of damages}

The expected damages have been assessed in accordance with European Macroseismic Intensity Scale, identifying the Vulnerability Class of the structure and assessing the expected damages in correlation with EMS intensity scale.

The definition of quantities is always centered to the most probable as follows: a few $\sim 5 \%$; many $30-40 \%$; most $70-100 \%$. The grades of damages are as follows:

- Grade 5, very heavy structural damage (total or near total collapse);

- Grade 4, heavy structural damage, very heavy non-structural damage (serious failure of walls; partial structural failure of roofs and floors);

- Grade 3, moderate structural damage, heavy non-structural damage (large and extensive cracks in most walls; roof tiles detach; chimney fracture at roof-line);

- Grade 2, moderate damage, slight structural moderate non-structural damages (cracks in infill walls, falling mortar);

- Grade 1, negligible to slight damage, no structural damage, slight non-structural damage (fine cracks in partitions and infill). 
The expected damages for all vulnerability classes and for the intensities VII and VIII are described in Table III.

The damages nearly all dwellings in the affected area and the unavoidable damages of the infrastructure will affect 5000 to 7000 people in the area. In this case the situation in western part of the Danube, e.g. in Paks and nearby villages are less severe (see Table III).

\section{Table III}

Expected damages in case of intensity VII and VIII

\begin{tabular}{|c|c|c|}
\hline Vulnerability class of structures & Intensity VII & Intensity VIII \\
\hline $\begin{array}{c}\mathrm{A} \\
\text { adobe }\end{array}$ & $\begin{array}{l}\text { Many buildings }(30-40 \%) \\
\text { suffer damage of Grade } 3 \text {. } \\
\text { A few }(\sim 5 \%) \text { buildings } \\
\text { suffer damage of Grade } 4 .\end{array}$ & $\begin{array}{l}\text { Many buildings }(30-40 \%) \\
\text { suffer damage of Grade } 4 . \\
\text { A few }(\sim 5 \%) \text { buildings } \\
\text { suffer damage of Grade } 5 .\end{array}$ \\
\hline $\begin{array}{c}\text { B } \\
\text { brick masonry }\end{array}$ & $\begin{array}{l}\text { Many buildings }(30-40 \%) \\
\text { suffer damage of Grade } 2 ; \\
\text { A few }(\sim 5 \%) \text { buildings } \\
\text { suffer damage of Grade } 3 \text {. }\end{array}$ & $\begin{array}{l}\text { Many buildings }(30-40 \%) \\
\text { suffer damage of Grade } 3 \text {. } \\
\text { A few }(\sim 5 \%) \text { buildings } \\
\text { suffer damage of Grade } 4 .\end{array}$ \\
\hline $\begin{array}{l}\text { C } \\
\text { reinforced masonry, frame non } \\
\text { designed for earthquake }\end{array}$ & $\begin{array}{l}\text { A few buildings }(\sim 5 \%) \\
\text { sustain damage of Grade } 2 .\end{array}$ & $\begin{array}{l}\text { Many buildings }(30-40 \%) \\
\text { suffer damage of Grade } 2 . \\
\text { A few }(\sim 5 \%) \text { buildings } \\
\text { suffer damage of Grade } 3 \text {. }\end{array}$ \\
\hline $\begin{array}{c}\mathrm{D} \\
\text { frame (earthquake resistance) }\end{array}$ & $\begin{array}{l}\text { A few buildings }(\sim 5 \%) \\
\text { sustain damage of Grade } 1 .\end{array}$ & $\begin{array}{l}\text { A few buildings }(\sim 5 \%) \\
\text { sustain damage of Grade } 2 .\end{array}$ \\
\hline
\end{tabular}

\subsection{Consequences of a Scenario 1 earthquake}

Assuming that a Scenario 1 earthquake happens, and applying the damage rates given in the Table III to the adobe (class A) and brick masonry buildings (class B and C) in the villages in Bács-Kiskun County (Table I), the damages in these villages can be obtained as it is shown in Table IV.

The masonry buildings evaluated in Table IV are of $92 \%$ of the total number of buildings in the villages in Bács-Kiskun County. Particularly, the expected damages for the Scenario 1 and within the area of intensity VIII are shown in Table V. The damages nearly all dwellings in the affected area, and the unavoidable damages of the infrastructure will affect 5000 to 7000 people in the area.

In this case the situation in western part of the Danube, e.g. in Paks and nearby villages are less severe, since this area is in the area of the intensity VII (see Table III for the differences between intensity VII and VIII damage rates).

\subsection{Consequences of a Scenario 2 earthquake}

From the point of view of logistical support of the plant emergency personnel the situation in Paks and in the nearby villages are of most interest. From this point of view the Scenario 2 has to be evaluated, when the epicenter is just below the site and the 
intensity area covers more the settlements where the operating personnel is living. The results of damage assessment for Paks are shown in Table VI.

Table IV

Expected damages in villages of Bács-Kiskun County

\begin{tabular}{|c|c|c|c|c|}
\hline $\begin{array}{c}\text { Type of } \\
\text { structure }\end{array}$ & $\begin{array}{l}\text { Vulnerability } \\
\text { Class }\end{array}$ & $\begin{array}{c}\text { Shear, } \\
\%\end{array}$ & $\begin{array}{c}\text { Vulnerability rate in the } \\
\text { area with radius } 10 \mathrm{~km} \\
\text { EMS VIII - heavily } \\
\text { damaging }\end{array}$ & $\begin{array}{l}\text { Vulnerability rate in the } \\
\text { area between } 10 \text { to } 30 \mathrm{~km} \\
\text { radius } \\
\text { EMS VII, damaging }\end{array}$ \\
\hline Adobe & A & 51.3 & $\begin{array}{ll}- & \text { many, 30-40\% of the } \\
\text { buildings suffer } \\
\text { Grade } 4 \text { damage } \\
\text { - } & \text { few, } 5 \% \text { of the } \\
\text { buildings suffer } \\
\text { Grade } 5 \text { damage }\end{array}$ & 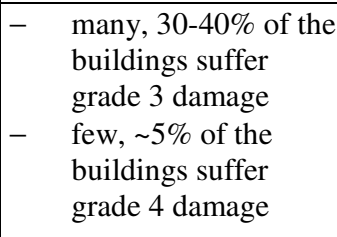 \\
\hline brick & B & \multirow[t]{2}{*}{40.9} & \multirow{2}{*}{ 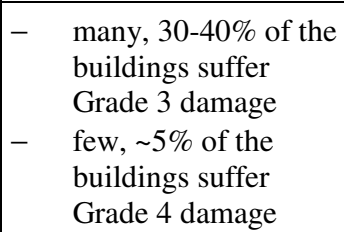 } & \multirow{2}{*}{ 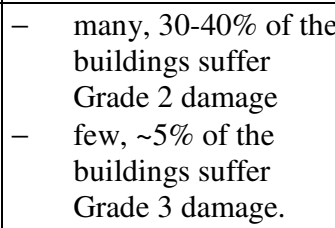 } \\
\hline $\begin{array}{l}\text { brick } \\
\text { building } \\
\text { with wreath }\end{array}$ & $\mathrm{B} / \mathrm{C}$ & & & \\
\hline
\end{tabular}

Table V

Expected damages in the area of intensity VIII for Scenario 1

\begin{tabular}{|c|c|c|c|}
\hline \multicolumn{2}{|l|}{ Buildings inside EMS VIII area } & Damaged, $\%$ of total & $\begin{array}{c}\text { Number of } \\
\text { damaged }\end{array}$ \\
\hline brick, stone, masonry hand-made masonry & 1018 & $\begin{array}{l}50 \% \text { Grade } 3 \\
20 \% \text { Grade } 4\end{array}$ & 713 \\
\hline medium or large block, cast concrete blocks & 151 & $50 \%$ Grade 3 & 75 \\
\hline panel & 2 & Inongianifiont tun & \\
\hline wood & 7 & 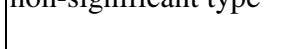 & 0 \\
\hline adobe with foundation & 826 & $\approx 80 \%$ Grade 4 & 826 \\
\hline adobe without foundation & 450 & $\approx 20 \%$ Grade 5 & 450 \\
\hline others & 34 & non-significant type & 0 \\
\hline Tota & 2487 & & 2064 \\
\hline
\end{tabular}

Practically two third of the buildings in Paks will be significantly damaged and nearly twenty thousand people will be affected by the consequence of the earthquake. The conditions in the town will be near catastrophic that cause essential psychological

Pollack Periodica 11, 2016, 2 
pressure on the personnel on duty and hinder the logistical support of the plant from outside.

Table VII consists the results for Dunaszentgyörgy that village also can be considered as a typical settlement, where also rather large number of plant personnel is living.

\section{Table VI}

Expected damages in the area of intensity VIII for Scenario 2

\begin{tabular}{|c|c|c|c|}
\hline \multicolumn{2}{|l|}{ Buildings inside EMS VIII area } & Damaged, $\%$ of total & $\begin{array}{c}\text { Number of } \\
\text { damaged }\end{array}$ \\
\hline brick, stone, masonry hand-made masonry & 2839 & \begin{tabular}{|l}
$50 \%$ Grade 3 \\
$20 \%$ Grade 4
\end{tabular} & 1987 \\
\hline medium or large block, cast concrete blocks & 526 & $50 \%$ Grade 3 & 263 \\
\hline panel & 482 & $20 \%$ Grade 3 & 96 \\
\hline wood & 12 & non-significant type & 0 \\
\hline adobe with foundation & 534 & $\approx 80 \%$ Grade 4 & 534 \\
\hline adobe without foundation & 289 & $\approx 20 \%$ Grade 5 & 289 \\
\hline others & 67 & non-significant type & 0 \\
\hline Total & 4750 & & 3169 \\
\hline
\end{tabular}

Table VII

Expected damages in the area of intensity VIII for Scenario 2

\begin{tabular}{|c|c|c|c|}
\hline \multicolumn{2}{|l|}{ Buildings inside EMS VIII area } & Damaged, $\%$ of total & $\begin{array}{c}\text { Number of } \\
\text { damaged }\end{array}$ \\
\hline brick, stone, masonry hand-made masonry & 522 & $\begin{array}{l}50 \% \text { Grade } 3 \\
20 \% \text { Grade } 4\end{array}$ & 365 \\
\hline medium or large block, cast concrete blocks & 38 & $50 \%$ Grade 3 & 19 \\
\hline panel & 0 & Inon-sionificant tyne & 0 \\
\hline wood & 0 & 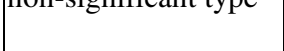 & \\
\hline adobe with foundation & 237 & $\approx 80 \%$ Grade 4 & 237 \\
\hline adobe without foundation & 202 & $\approx 20 \%$ Grade 5 & 202 \\
\hline others & 24 & non-significant type & 0 \\
\hline Total: & 1023 & & 823 \\
\hline
\end{tabular}


The earthquake consequences are even more severe in the villages around the plant. In Dunaszentgyörgy $80 \%$ of the houses will be significantly damaged and 2520 people will be affected by the earthquake.

\section{Other damages caused by earthquake}

Large part of the Pannonian Basin is covered by young Holocene fluvial sediments with high ground water level. Despite its moderate seismicity, several liquefaction cases have been documented during larger historical earthquakes, latest in Kecskemét (1911) and Dunaharaszti (1956). The soil at the investigated flood plain is highly susceptible to liquefaction [16]. Liquefaction affects the stability of the buildings causing additional losses to those listed from Table IV to Table VII. The high-voltage towers and the lifelines (water and gas piping) can also fail due to differential soil settlements. Roads and dykes can likewise be damaged due to liquefaction. Contrary to these the liquefaction causes limited damages of plant structures and the fundamental safety functions will be ensured [17] and [18].

There are several non-fixed loess slopes in the affected earthquake area that are susceptible to sliding due to ground shakings, e.g. along the old main road No 6 north to Paks.

The secondary phenomena (slope-sliding, liquefaction) also worsen the postearthquake situation. Vulnerability of lifelines is also worth of investigations; see, e.g. [19]. Important secondary effect of the damages are the fires that are sometimes more severe than the effects due to vibratory ground motion.

\section{Damage of the electrical grid}

In case of design basis earthquake, the NPP basic safety functions are ensured and cooling water and emergency power supply are ensured. However, the electrical grid will suffer huge damages, since the towers of the grid have been designed for wind and ice loads assuming that the (100 years) earthquake loads are bounded with lateral wind loads. Due to the damages of the grid, nearly half of the domestic production will fall out from the power system that causes the collapse of the national grid. The Hungarian Independent Transmission Operator Company Ltd (MAVIR) has a recovery plan for the grid. Rebuilding of the grid could last from several hours to several days, depending on the severity of the damages. The NPP could stay in safe mode minimum one week or unlimited long if the fuel supply for emergency diesel generators is continuous. It is also possible to operate one of the units on the reduced power level and ensure safe power supply for all units. The substation and the high-voltage towers at the NPP site have been upgraded for the design basis earthquake and these infrastructures will withstand the earthquake. Thus, the NPP will be a stable connection point for restoring the national grid as fast as possible. Since the NPP is the biggest producer in the country it's impossible to restore the grid without the NPP. If all units are out of operation then for the restart for the first unit needs offsite power. Therefore there are two independent transmission lines tested to transmit $\sim 20 \mathrm{MW}$ capacity to the NPP. 


\section{Conclusions}

Case studies performed provide insight what damages and post-earthquake situation can be expected when a design basis earthquake with return period ten thousand years hit the Paks Nuclear Power Plant. The damages of the housing in the area will be rather catastrophic while the basic safety function of the Paks Nuclear Power Plant is ensured. The detailed evaluation of the post-earthquake situation in the area around the plant site helps us to prepare the emergency and recovery programs.

\section{References}

[1] WENRA, Design extension of existing reactors, Issue F, Western European nuclear safety regulators, 29 September 2014, Guidance Document, http://www.wenra.org/media/ filer_public/2014/10/28/wenra-rhwg_guidance_on_issue_f.pdf, (last visited 8 December 2015).

[2] WENRA, Natural hazards, Head document, Issue T, Western European nuclear safety regulators, 21 April 2015, Guidance document http://www.wenra.org/media/ filer_public/2015/04/23/wenra-rhwg_t1_guidance_on_issue_t_head_document_2015-0421.pdf_(last visited 8 December 2015).

[3] Katona T. J., Seismic safety analysis and upgrading of operating nuclear power plants, In: Nuclear power, practical aspects, Wael A. (Ed.), InTech, Rijeka, Ch. 4, 2012.

[4] HAEA, National report of Hungary on the targeted safety re-assessment of Paks nuclear power plant, Hungarian Atomic Energy Authority, Budapest, 29 December 2011.

[5] Hornyacsek, J. Earthquake! Are we prepared? (in Hungarian) Hadmérnök, Vol. VI, No. 1, 2011, pp. 276-295.

[6] Nagy S. Relation of the local disaster management authorities and risk forecasts, (in Hungarian) Hadtudomány Vol. 3-4, 2014, pp. 124-132.

[7] Whitman R. V., Anagnos T., Kircher C. A., Lagorio H. J., Lawson R. S., Schneider P.) Development of a national earthquake loss estimation methodology, Earthquake Spectra, Vol. 13, No. 4, 1997, pp. 643-661.

[8] Alexander D. Principles of emergency planning and management, Terra Publishing, 2002.

[9] Perry R. W., Lindell M. K. Preparedness for emergency response, Guidelines for the emergency planning process, Disasters, Vol. 27, No. 4, 2003, pp. 336-350.

[10] Tyagunov S., Grünthal G., Wahlström R, Stempniewski L., Zschau J. Seismic risk mapping for Germany, Natural Hazards and Earth System Sciences, Vol. 6, 2006, pp. 573-586.

[11] Gueguen Ph., Michel C., LeCorre L. A simplified approach for vulnerability assessment in moderate-to-low seismic hazard regions, application to Grenoble (France), Bull Earthquake Eng. Vol. 5, No. 3, 2017, pp. 467-490.

[12] Population census held in 2011 and published by the Hungarian Central Statistical Office, Housing Data, Központi Statisztikai Hivatal, 2011 évi népsyámlálás, 12. Lakásviszonyok, Budapest, 2014, http://www.ksh.hu/nepszamlalas/, (last visited 8 December 2015).

[13] EMS-98 European Macroseismic Scale 1998, Grünthal, G. (Ed.), Centre Europèen de Géodynamique et de Séismologie, Luxembourg, 1998,

[14] Calvi G. M., Pinho R., Magenes G., Bommer J. J., Restrepo-Vélez L. F., Crowley H. Development of seismic vulnerability assessment methodologies over the past 30 years, ISET Journal of Earthquake Technology, Paper No. 472, Vol. 43, No. 3, 2006, pp. 75-104.

[15] Fódi A., Bódi I. Comparison of shear behavior of masonry walls with and without reinforcement, Pollack Periodica, Vol. 5, No. 3, 2010, pp. 71-82. 
[16] Győri E., Mónus P., Bán Z., Tóth L. Conclusions reached from environmental effects of historical earthquakes occurred in the Pannonian Basin, 26th General Assembly of the International Union of Geodesy and Geophysics, Prague, Czech Republic, 22 June 22 - 2 July 2015, Paper S01dp-577.

[17] Katona T. J, Safety assessment of the liquefaction for nuclear power plants, Pollack Periodica, Vol. 10, No. 1, 2015, pp. 39-52.

[18] Katona T. J., Győri E., Bán Z., Tóth L. Assessment of consequences for nuclear power plant Paks, Transaction of $23^{\text {rd }}$ Conference on Structural Mechanics in Reactor Technology, SMiRT-23, Manchester, United Kingdom, 10-14 August 2015, Division VII, Paper ID 125.

[19] Menoni S., Pergalani F., Boni M. P., Petrini V. Lifeline earthquake vulnerability assessment, A systemic approach, In: I. Linkov, G. Kiker, R. Wenning (Eds.) Environmental Security in Harbors and Coastal Areas, Springer, 2012, pp. 1-24. 